\title{
$\sqrt{ }$ Notes
}

\section{Potential for Minimally Tilled, Fall- planted Brassicas in Hill Land Permaculture Sites}

\section{D.J. Makus'}

Hill lands of the upper mid--southern United States generally receive $>100 \mathrm{~cm}$ of rain annually and are highly erodible if cultivated. Cow-calf operations, which dominate the area, return about $\$ 150 /$ acre annually if conditions are favorable. Integrating high-value cash crops into such systems has economic merit

Research objectives were to determine the yield potential of three cultivars of brassicas in minimally and moderately disturbed planting sites to compare the yield of these cultivars to conventionally tilled brassicas and to examine edaphic differences under these tillage systems,

On 8 Aug. 1991, the minimum tillage site was sprayed with glyphosate (1,6 lb/acre, a.i,) Two treatments were performed on 3 Sept: 1) chiseling to an 18-inch depth, and 2) strip-rototilling to 4 inches after chiseling, A third treatment was established by conventional discing and forming 8-inch raised beds, Dacthal (chlorothal) and diazinon were applied to all treatments at 6 and $0.38 \mathrm{lb} / \mathrm{acre}$ a.i., respectively. Threeweek-old brassica transplants of 'Snow Crown' cauliflower (Brassica o/eracea var. botrytis L.), 'Charmont' cabbage (B. oleracea var. capitata L.), and 'Packman' broccoli (B. oleracea var. italica Plenck) were transplanted into the field on 4 Sept. at 18 -inch spacings in rows on $3-\mathrm{ft}$ centers. Plot length was $36 \mathrm{ft}$ and each treatment was replicated four times in a completely randomized design, An initial fertilizer application of $10 \mathrm{~N}-20 \mathrm{P}-20 \mathrm{~K}$ at $200 \mathrm{lb} / \mathrm{acre}$ was banded over the row centers. Biwall drip irrigation tubing with a discharge of $0.47 \mathrm{gal} / 100 \mathrm{ft}$ per min was used to supply water and/or supplemental irrigation A 5N-IIP-26K water-soluble fertilizer was added weekly for 7 consecutive weeks to supply a total of $43 \mathrm{~N}-89 \mathrm{P}-156 \mathrm{~K}$ (lb/acre) at the end of the 7 th week.

Broccoli and cabbage yields from killed sod, strip-rototilled pasture compared favorably to yields of conventionally grown plants; unlike cauliflower yields, which were $42 \%$ lower in the conservation tillage systems. Minimal tillage systems conserved soil moisture but delayed maturity (in broccoli), reduced the soil $\mathrm{NO}_{3}-\mathrm{N}$ to $\mathrm{NH}_{4}-\mathrm{N}$ ratio, and reduced the soil nitrate content in the upper 0 to 6 inches of soil, Soil compaction, as measured by bulk density and penetrometer, were higher in the chiseled system, but only if soil compaction was measured in a nonchiseled area (e.g., 6 inches parallel from the chisel path), Soil temperatures at a 6-inch depth were similar between tillage systems, but the mean daily soil temperatures in the conventionally bedded system were higher earlier in the season and lower late in the season compared to soil temperatures in the minimal tillage systems,

Overall benefits of no-till management include less soil disturbance and preparation, better accessibility to fields during inclement weather, and reduced risk of soil erosion, Given adequate weed control, water usage also may be reduced by conservation tillage. With modest fertilizer inputs, broccoli yields of $63 \mathrm{cwt} /$ acre from strip-rototilled grazing lands are possible.

USDA/ARS, Family Farm Research Center, Bonneville, AR 72927.

${ }^{\prime}$ Research Horticulturist. 